\title{
Draft Genome Sequence of the Extremely Halophilic Phototrophic Purple Sulfur Bacterium Halorhodospira halochloris
}

\author{
Kumar Saurabh Singh ${ }^{1}$, Jared Kirksey ${ }^{2}$, Wouter D. Hoff ${ }^{3}$ and Ratnakar Deole ${ }^{\circledR}$ \\ 1. School of Biosciences and Veterinary Medicine, University of Camerino, 62032 CAMERINO (MC) ITALY. \\ 2. Department of Natural Sciences, Northeastern State University, Broken Arrow, OK, USA; \\ 3. Department of Microbiology and Molecular Genetics, Oklahoma State University, Stillwater, OK, USA.
}

$\triangle$ Corresponding author: Ratnakar Deole, Department of Natural Sciences, Northeastern State University, Broken Arrow, OK, USA.

(c) Ivyspring International Publisher. This is an open-access article distributed under the terms of the Creative Commons License (http://creativecommons.org/ licenses/by-nc-nd/3.0/). Reproduction is permitted for personal, noncommercial use, provided that the article is in whole, unmodified, and properly cited.

Published: 2014.07.06

\begin{abstract}
Halorhodospira halochloris is an extremely halophilic bacterium isolated from hypersaline Wadi Nantrun lakes in Egypt. Here we report the draft genome sequence of this gammaproteobacteria (GI number: 589289709, GenBank Accession number: CP007268). The 3.5-Mb genome encodes for photosynthesis and biosynthesis of organic osmoprotectants. Comparison with the genome of H.halophila promises to yield insights into the evolution of halophilic adaptations.
\end{abstract}

Key words: Halorhodospira halochloris, genome sequence

\section{Introduction}

Halorhodospira halochloris is an anoxygenic photosynthetic halophile that was isolated from the hypersaline Wadi Natrun lakes in Egypt, residing in the mats near the sediments (8). H. halochloris belongs to the class of $\gamma$-Proteobacteria $(3,7)$. The genus Halorhodospira was formed by separating species $H$. halophila, H. halochloris and H. abdelmalekii from genus Ectothiorhodospira based on their 16S rRNA sequences $(4,6)$. H. halochloris is obligately anaerobic and phototrophic. Its cells are vibroid, motile by bipolar flagella and have internal photosynthetic membranes as lamellar stacks (13). H. halochloris exhibits growth over an unusually wide range of medium $\mathrm{NaCl}$ concentrations and is capable of growth down to 5\% $\mathrm{NaCl}$, which is unusual for extremely halophilic bacteria.

Halophilic bacteria employ two differing strategies to protect their cytoplasmic volume against osmotic movement of water to the hypersaline environment (12). Both strategies work by increasing the internal osmolarity of the cell. In the first, organic compounds are accumulated in the cytoplasm - these osmoprotectants are known as compatible solutes. The second biochemically, more radical adaptation involves the selective influx of $\mathrm{K}^{+}$ions into the cytoplasm.

$H$. halochloris accumulates glycine betaine (N,N,N-trimethylglycine), a compatible solute as its osmoprotectant (5). In addition to its osmoprotectant activity, glycine betaine also provides protection against mutagenic compounds and radiation-induced damage (9). Glycine betaine can either be taken up directly from the environment, or be synthesized de novo (11). We recently used isoelectric focusing of total cell proteins to demonstrate that $H$. halochloris does not exhibit an acidic proteome, matching its inability to accumulate $\mathrm{K}^{+}(2)$. In striking contrast we found that a closely related organism $H$. halophila accumulates molar concentrations of $\mathrm{KCl}$ when grown in high salt medium and has an acidic proteome. 
These observations indicate recent evolutionary changes in the osmoprotection strategy of these organisms. Comparative genomics of $H$. halochloris and $H$. halophila promises to provide insights into this issue, which has implications both for genome-wide evolutionary processes and the mechanisms of halophilic adaptations. These considerations led us to determine the genome of H.halochloris, which we report on here.

Little genome data are currently available for the Halorhodospira and related Ectothiorhodospira. Recently we reported the complete genome of $\mathrm{H}$. halophila (1). In this study, we report the draft genome sequence of $H$. halochloris, which was obtained through Standard Roche 454 pyrosequencing using the Roche 454-Junior instrument. The raw data obtained were trimmed at either end based on the quality score analysis performed using fastQC tool. Poor or bad quality bases, probably originating from sequencing mis-calls, were trimmed off before subjecting it to the assembly software. We performed genome assembly using three different assemblers, namely Newbler (16), MIRA (17) and PHRAP (18), with the default set of parameters. After comparisons of these assembly attempts based on contig sizes, genome representation and its functional elements, the output of MIRA 3.4.1 was selected to proceed with further analysis. The final output had some low quality contigs in terms of length and average coverage. All contigs of length less than $1 \mathrm{Kbp}$ and average coverage $<10$ were removed as being uninformative, from annotation point of view, and subjected to an individual annotation check using BLAST (14). Most of these individual contigs yielded relatively high e-value or no scores with halophiles. Eventually 139 contigs were selected for further analysis. Processed contigs were mapped against a distant reference genome (Thioalkalivibrio sulphidophilus), as no true known reference genome is currently available, based on $16 \mathrm{~S}$ analysis, using CONTIGuator (15). The assembled scaffold comprises 137 contigs, 3,460,134 bases at 20 fold coverage and has a GC content of $63 \%$. For comparison the genome of $H$. halophila is $2.7 \mathrm{Mb}$ in size and has GC content of $67 \%$ (1).

The JGI IMG/ER Annotation pipeline (http://img.jgi.doe.gov/er) was employed for gene annotation with IMG Submission ID and IMG Project ID, 15725 and 50543 respectively. The numbers of tRNA and rRNA genes were predicted as 46 and 8, respectively. A total of 3,301 putative protein coding genes (CDSs) or open reading frames (ORFs) were predicted with a total gene count of 3,376. The genome has been submitted in public databases, NCBI,
Genbank (GI number: 589289709, GenBank Accession number: CP007268).

The draft genome information reported here provides opportunity for further research into the mechanism involved in halophilic adaptations and allow organisms to thrive in hyper saline environments, how these evolve and how they differ for bacteria and archaea (10).

\section{Supplementary Material}

Supplementary Report.

http://www.jgenomics.com/v02p0118s1.pdf

\section{Acknowledgements}

We would like to thank Dr. Peter Hoyt of Oklahoma State University, Genome sequencing facility for sequencing the genome and providing valuable advice during this project. This research was supported by internal grant from Northeastern State University, Faculty Research Council, 2012. WDH is supported by NSF grant MCB-1051590 and MRI-1338097.

\section{Competing Interests}

The authors have declared that no competing interest exists.

\section{References}

1. Challacome J, Majid S, Deole R, Brettin TS, Delano SF, Gleasner CD, Detter J, Han CS, Misra M, Reitenga KG, Saunders E, Tapia R, Lapidus A, Ivanova N, Hoff WD. Complete genome sequence of Halorhodospira halophile SL1. Standards in Genome Science. 2013; 8: 206-214.

2. Deole R, Challacombe J, Raiford DW, Hoff WD. An Extremely Halophilic Proteobacterium Com-bines a Highly Acidic Proteome with a Low Cytoplasmic Potassium Content. J Biol Chem. 2012.

3. Imhoff J. Halophilic phototrophic bacteria vol 1. Boca Raton: CRC Press. 1988.

4. Imhoff J. The Family Ectothiorhodospiraceae. In: Dworkin M, et al, ed. The Prokaryotes. New York: Springer. 2006: 874-886.

5. Imhoff JF, and Rodriguez-Valera F. Betaine is the main compatible solute of halophilic eubacteria. J Bacteriol. 1984; 160:478-479.

6. Imhoff JF, and Süling J. The phylogenetic relationship among Ectothiorhodospiraceae: a reevaluation of their taxonomy on the basis of $16 \mathrm{~S}$ rDNA analyses. Archives of Microbiology. 1996; 165:106-113.

7. Imhoff JF, Hashwa F, and Truper H. Isolation of extremely halophilic phototrophic bacteria from the alkaline Wadi Natrun, Egypt. Archiv fuer Hydrobiologie. 1978;84:381-388.

8. Imhoff J, Sahl HG, Soliman GH, and Truper HG. The Wadi Natrum: chemical composition and microbial mass development in alkaline saline brines of entropic desert lakes. Journal of Geomicrobilogy. 1979; 1:219-234.

9. Ji C, and Kaplowitz N. Betaine decreases hyperhomocysteinemia, endoplasmic reticulum stress, and liver injury in alcohol-fed mice. Gastroenterology. 2003; 124:1488-1499.

10. Mongodin EF, et al. The genome of Salinibacter ruber: convergence and gene exchange among hyperhalophilic bacteria and archaea. Proceedings of National Academy of Sciences. 2005;102:18147-18152.

11. Nyyssölä A, Kerovuo J, et al. Extreme Halophiles Synthesize Betaine from Glycine by Methylation. Journal of Biological Chemistry. 2000; 275:22196-22201.

12. Oren A. Microbial life at high salt concentrations. Saline Systems. 2008;4:2.

13. Raymond JC, Sistrom WR. The isolation and preliminary characterization of a halophilic photosynthetic bacterium. Arch Mikrobiol 1967; 59:255-268. 
14. Altschul S.F., Gish W., Miller W., Myers E.W, Lipman D.J. Basic local alignment search tool. J Mol Biol. 1990; 215:403-410.

15. Galardini $\mathrm{M}$, et al. A bacterial genomes finishing tool for structural insights on draft genomes. Source Code for Biology and Medicine 2011; 6:11. doi:10.1186/1751-0473-6-11.

16. Margulies M, Egholm M, Altman WE, Attiya S, Bader JS, Bemben LA, Berka J, Braverman MS, Chen YJ, Chen Z, Dewell SB, Du L, Fierro JM, Gomes XV, Godwin BC, He W, Helgesen S, Ho CH, Ho CH, Irzyk GP, Jando SC, Alenquer ML, Jarvie TP, Jirage KB, Kim JB, Knight JR, Lanza JR, Leamon JH, Lefkowitz SM, Lei M, Li J, Lohman KL, Lu H, Makhijani VB, McDade KE, McKenna MP, Myers EW, Nickerson E, Nobile JR, Plant R, Puc BP, Ronan MT, Roth GT, Sarkis GJ, Simons JF, Simpson JW, Srinivasan M, Tartaro KR, Tomasz A, Vogt KA, Volkmer GA, Wang SH, Wang Y, Weiner MP, Yu P, Begley RF, Rothberg JM. Genome sequencing in microfabricated high-density picolitre reactors. Nature $2005 ;$ 437:376-380.

17. Chevreux B, Wetter T, Suhai S. Genome Sequence Assembly Using Trace Signals and Additional Sequence Information. Computer Science and Biology: Proceedings of the German Conference on Bioinformatics (GCB). 1999; 99:45-56.

18. Machado M, et al. Phred-Phrap package to analyses tools: a pipeline to facilitate population genetics re-sequencing studies. Investig Genet. 2011; 2(1):3. doi: 10.1186/2041-2223-2-3. 